\section{London's agony (contd.)}

The University of London may surprisingly have become a model of good administration.

The University of London is the British university system in microcosm, but with the added disadvantages that its budget is more vulnerable to the flight of high fee paying students from overseas and that its administration is poorly suited to making decisions, even of the simplest kind. This week, the university has told its constituent parts how much money from the centre they will have to spend in the financial year that began more than two months ago, on 1 August. On this occasion, however, the delay is partially forgivable, for the court of the university, formally responsible for money matters that do not involve questions of academic policy (whatever they may be), has been uncustomarily decisive. In particular, it has broken out of the mould in which it had become trapped of sharing its funds as they had happened to be shared in the previous year, with allowances for special pleading on the side. Even so, much remains to be done.

The university's constitutional difficulty stems from the notional autonomy of the parts of which it is composed. Formally, the university cannot tell one of its constituent colleges how to conduct its affairs except by insisting through a cumbersome network of committees that acceptable academic standards should be followed and by doling out funds in such a way as to encourage or discourage various activities. (In dealings from the centre with individual universities in the United Kingdom, the University Grants Committee responsible for sharing out the government subvention of universities can only command the second weapon, at least in the short term.) Two years ago and then last year, the university somewhat arbitrarily told its colleges what they would have to spend in the succeeding years without explaining how the figures had been decided, except for the still puzzling and unwarrantable decision that courses combining two different lines of study should be discouraged. This year, the university has told its dependants how it has done its sums.

To its credit, the university has also devised an important innovation, and has decided that constituent colleges able to attract substantial amounts of research income should be paid extra on that account. This decision is entirely consistent with all that has been said in recent months about the collapse of what is called the dual-support system, by means of which the general university subvention is meant to cover the overhead cost of carrying out research (but nobody likes the word "overhead"). This is the most tangible way in which the university can substantiate its frequently expressed hope that research will survive all the troubles there have been. The failure to follow such procedures in recent years has unfairly robbed of funds those colleges with strong traditions in research but which for other reasons have been dealt with meanly within the university.

It is also sensible that in this first year, the university should have followed the logic of its conclusion that research requires extra support only part of the way, to the tune of one-third of what will be done two years from now. One of the ironies of the redistribution in the coming year is that the only one of the nine regular undergraduate schools to gain funds as a result, Queen Elizabeth College, is one of those dealt with most severely last year. (Imperial College deals separately with the University Grants Committee, while the London School of Economics has no substantial amount of research in scientific subjects.) The end result of this new arrangement is certain to be that the different parts of the university will have an incentive to improve their research. Should not the British system as a whole now promptly follow suit?

The university has also been sensible in planning for a reduction of the number of its parts. While it remains to be clearly demonstrated that small colleges with only about a thousand or so students are inviable, there is something in the view that concentration would help and might be cheaper. That course of action is at least worth a try. So colleges with plans to merge with each other are now offered a modest incentive - an increase of combined student numbers - and possibly a share of the pot of money the university is salting away meanwhile. Exactly such incentives would have allowed the University Grants Committee, in its dealing with the British universities collectively, to help rationalize the system without as much pain as there has been. In London, with the university's new-found taste for open government, what remains to be done is to explain exactly why those colleges that will find life even more difficult if they choose to stand alone have been singled out for such a fate, and to make more durable arrangements than now exist for making sure that potential casualties of the rearrangement, people and institutions, are not discarded without thought.

\section{Soviet science not quoted}

\section{Why are Soviet papers less often cited by US authors than in the 1970s? Secrecy? Or quality?}

Is Soviet science approaching a crisis of quality? Or is the regime becoming more and more secretive about its good science? These questions, which have an important bearing on international science policy and questions of technology transfer, are attracting much attention. Although the data to answer them are scant, some trends are arresting. Thus in the field of mathematics, US scientists have been citing Soviet work less and less; US citations of Soviet mathematics declined by 48 per cent from 1973 to 1979 (see Nature 30 September, p.388). More recent unpublished data from the National Science Foundation suggest that the decline is now 53 per cent.

Why would US authors make less and less use of Soviet mathematics - a field in which that country is believed to excel? The principal translators of Soviet mathematical work in the United States are the American Mathematical Society, in Providence, Rhode Island, and Plenum Press in New York. (The latter is a principal source of translating and distributing foreign scientific materials, especially materials from Eastern bloc countries.) Both organizations report that, if anything, they are translating and distributing more Soviet mathematics papers than they did a decade ago. So the decline in citations is not apparently connected with a decline in the amount of material available in translation in the United States. Another explanation has unexpectedly turned up in a study for the US Department of State carried out by Computer Horizons Inc., a New Jersey corporation. Francis Narin, president of the corporation, says that there are two distinctly different groups of highly cited Soviet scientific papers: those describing work of the highest quality which is cited over and over again, and those which are cited of ten by Soviet scientists but much less often elsewhere. It seems as if Soviet authors look to one group of Soviet mathematicians while Western authors look to another. The study was too preliminary to show whether the work in the two sets of papers is related, but Narin has established that the papers cited by Westerners were not merely translations of those cited most by the Soviet scientists. The results so far are, however, a telling illustration of what citation analysis may eventually accomplish in this important field.

Meanwhile, speculation about the causes of these changes flourishes. To many US academics, it seems natural to account for what is happening as a consequence of Soviet classification policy. The case of computer science and its applications is often mentioned: in the United States, most work not strictly related to defence and commercial development is published freely, while in the Soviet Union the opposite is true. But the past decade has also seen more modest declines in the frequency of US citations of Soviet work in physics and the Earth and space sciences, while US citations of work in these fields by other than Soviet nationals have risen dramatically. So there is again speculation that the Soviet Union may be hiding its best work. For the time being, US academics do not accept that there has been a decline of quality of Soviet research. But they are intrigued at the possibility that citation analysis could help them find out. 